The International Journal of

\title{
Educational Organization and Leadership
}

Investigating Principal Transformational Leadership in Strengthening Lonto Leok's Cultural-based Character Education 


\section{EDITOR}

Bill Cope, University of Illinois at Urbana-Champaign, USA

Mary Kalantzis, University of Illinois at Urbana-Champaign, USA

ACTING DIRECTOR OF PUBLISHING

Jeremy Boehme, Common Ground Research Networks, USA

\section{EDITORIAL ASSISTANT}

Kortney Sutherland, Common Ground Research Networks, USA

\section{ADVISORY BOARD}

The Advisory Board of The Learner Research Network recognizes the contribution of many in the evolution of the Research Network. The principal role of the Advisory Board has been, and is, to drive the overall intellectual direction of the Research Network. A full lis of members can be found at https://thelearner.com/about/advisory-board.

\section{PEER REVIEW}

Articles published in The International Journal of Educational Organization and Leadership are peer reviewed using a two-way anonymous peer review model. Reviewers are active participants of The Learner Research Network or a thematically related Research Network. The publisher, editors, reviewers, and authors all agree upon the following standards of expected ethical behavior, which are based on the Committee on Publication Ethics (COPE) Core Practices. More information can be found at https://cgnetworks.org/journals/publication-ethics.

\section{ARTICLE SUBMISSION}

The International Journal of Educational Organization and Leadership publishes biannually (June, December). To find out more about the submission process, please visit https://thelearner.com/journals/call-for-papers.

THE INTERNATIONAL JOURNAL OF EDUCATIONAL ORGANIZATION AND LEADERSHIP

https://thelearner.com

ISSN: 2329-1656 (Print)

ISSN: 2329-1591 (Online)

https://doi.org/10.18848/2329-1656/CGP (Journal)

First published by Common Ground Research Networks in 2020 University of Illinois Research Park

2001 South First Street, Suite 202

Champaign, IL 61820 USA

Ph: +1-217-328-0405

https://cgnetworks.org

The International Journal of Educational Organization and Leadership is a peer-reviewed, scholarly journal.

\section{COPYRIGHT}

(C) 2020 (individual papers), the author(s)

(C) 2020 (selection and editorial matter),

Common Ground Research Networks

All rights reserved. Apart from fair dealing for the purposes of study, research, criticism, or review, as permitted under the applicable copyright legislation, no part of this work may be reproduced by any process without written permission from the publisher. For permissions and other inquiries, please contact cgscholar.com/cg_support.

\section{Crossref}

Common Ground Research Networks, a member of Crossref

\section{ABSTRACTING AND INDEXING}

For a full list of databases in which this journal is indexed, please visit https://thelearner.com/journals/collection.

\section{RESEARCH NETWORK MEMBERSHIP}

Authors in The International Journal of Educational Organization and Leadership

are members ofThe Learner Research Network or a thematically related Research Network. Members receive access to journal content. To find out more, visit

https://thelearner.com/about/become-a-member.

\section{SUBSCRIPTIONS}

The International Journal of Educational Organization and Leadership is available in electronic and print formats. Subscribe to gain access to content from the current year and the entire backlist. Contact us at cgscholar.com/cg_support.

\section{ORDERING}

Single articles and issues are available from the journal bookstore at https://cgscholar.com/bookstore.

\section{OPEN RESEARCH}

The International Journal of Educational Organization and Leadership is Hybrid Open Access, meaning authors can choose to make their articles open access. This allows their work to reach an even wider audience, broadening the dissemination of their research To find out more, please visit https://cgnetworks.org/journals/openresearch.

\section{DISCLAIMER}

The authors, editors, and publisher will not accept any legal responsibility for any errors or omissions that may have been made in this publication. The publisher makes no warranty, express or implied, with respect to the material contained herein. 


\title{
Investigating Principal Transformational Leadership in Strengthening Lonto Leok's Cultural-based Character Education
}

\author{
Yulius Rustan Effendi, ${ }^{1}$ Universitas Negeri Malang, Indonesia \\ Ibrahim Bafadal, Universitas Negeri Malang, Indonesia \\ I Nyoman Degeng Sudana, Universitas Negeri Malang, Indonesia \\ Imron Arifin, Universitas Negeri Malang, Indonesia
}

\begin{abstract}
This study aimed to portray the process of applying local cultural moral values (LCMV) that have not been prioritized by the Indonesian Ministry of Education, as the values of the main character standards in schools. In addition, principals' transformational leadership behavior (TLB) is described based on the local culture teaching dimension approach. This research used a qualitative approach with the case study design. To achieve the research objectives, data were collected through in-depth interviews, participant observation, and document analysis. Data analysis used a modified analytic analysis method. Data validity was drawn on credibility, transferability, dependability, and confirmability. The results of the study demonstrated that LCMV supports strengthening the character of students, and the application of TLB based on the local culture teaching dimension approach is severely effective in optimizing the implementation of character education strengthening programs (CESP). This research was conducted in 2018-2019 at the State Junior High School in the West Flores region, Indonesia. The results of this research will be recommended to the Indonesian Ministry of Education, to use LCMV as a standard character value in schools and provide opportunities for principals in each school to implement a leadership model based on local culture approaches.
\end{abstract}

Keywords: Transformational Leadership, Strengthening Character Education, Character Values, Dimensions of Teaching Lonto Leok

A dvancement in the global era unites human potential without limits, in thinking, communicating, and acting, encouraging changes in various fields, including education (Cook et al. 2016). The changes that occur cause the strengthening of individual autonomy in building identity and morality (Veugelers 2008) but position humans in a dilemmatic situation. However, tough competitiveness has had the impact of losing critical awareness of humanity among people (Lovvorn and Chen 2011). This losing of critical awareness of humanity is currently experienced by students at the junior high school level in Indonesia. Actions of moral perversion are shown in forms such as; intolerant attitudes that give birth to radical groups; fights between students; drug use; promiscuity; cheating; stealing; unethical dress; undisciplined, impolite, unethical speaking; and losing the meaning of the values of local cultural wisdom (Ministry of Education 2016).

Responding to moral deviations, the Indonesian Ministry of National Education has established a character education strengthening program (CESP) to continue the implementation of character education that has been in place since 2010. The Indonesian government revitalized the national education policy through the Government Regulation of the Republic of Indonesia number 87 of 2017, on character education strengthening (CES), Chapter I, article 1, which emphasized that CESP includes pedagogical activities that unite the heart, taste, mind, and body. Government regulations are important to be implemented in schools, as an anticipatory and curative step in overcoming moral deterioration that occurs among students. This regulation

\footnotetext{
${ }^{1}$ Corresponding Author: Yulius Rustan Effendi, Work Postal Address/Physical Address, Department, Affiliated Organization, City, State, Postal Code, Country. email: address@email.edu
}

The International Journal of Educational Organization and Leadership

Volume \#, Issue \#, 20\#\#, https://thelearner.com

(C) Common Ground Research Networks, Yulius Rustan Effendi, Ibrahim Bafadal,

I Nyoman Degeng Sudana, Imron Arifin, All Rights Reserved.

Permissions: cgscholar.com/cg_support

ISSN: 2329-1656 (Print), ISSN: 2329-1591 (Online)

https://doi.org/\#\#\#\#\#\#\#\#\#\#\#\#\#\#\#\#\#\#\# (Article) 
is implemented through intensive coordination with teachers, employees, students, parents, school committees, and the community, including the important role of the principal.

Even though the Indonesian government has revitalized national education policies, the CESP has not been implemented optimally in schools. The cause of failure is the policy and an approach pattern of school principals who do not support the values of CES. First, the principal's policy of establishing national character values (NCV) as the main character values in schools is considered impractical and not contextual. It occurs since NCV is conceptual and does not have leok cultural moral values (LLCMV); it also have practical political content (Wibowo 2015; Koesoema 2015). Indonesian people share different ethnic and cultural norms (Kleden 1987). Therefore, the standards of character values set in schools must follow the values and norms of local culture that have been integrated with the life experience of students. If NCV are still used, local students are alienated from their environment and experience an identity crisis. Their life behavior will not follow the demands of their own moral values and culture.

Second, the pattern of the approach used by school principals is not relevant to local culture (Ardiawan 2018). This is because a leader needs to adjust his/her approach pattern to culture in the work environment, and cultural characteristics that blend with patterns of experiences (Bass 1997; Den Hartog et al. 1999). According to Leithwood and Jantzi (1999), this condition will shape contextual work performance that is appropriate to the culture and climate of an organization. This statement is in accordance with research findings of Tapung et al. (2018), who examined the impact of planting the value of lonto leok in the study of social sciences in junior high and high school students in Manggarai Regency, West Flores, Eastern Indonesia. Lonto leok is a cultural heritage that is valuable for the life of the Manggarai community. The cultivation of lonto leok values in learning successfully shapes students' social character, thereby overcoming students' social problems. Sutam (2014) examined the impact of applying the lonto leok culture by a leader in Manggarai and found positive acceptance of the role of a leader by the Manggarai community using the lonto leok culture teaching dimension approach (LLCTDA).

Irawanto, Ramsey, and Ryan (2011) also found changes in performance in subordinates when leaders used the paternalistic leadership patterns of Javanese culture in the Provincial Government of the Yogyakarta Capital Region. Yunus (2015) examined the impact of the transformation of "Huyula" cultural values in building the nation's character in the city of Gorontalo, South Sulawesi Province. Research by Surya et al. (2014) found a positive influence on the culture of "Tri Hita Karana" applied by leaders so that the company's performance was more advanced. When reviewing previous research with the research we conducted, we found significant differences. Previous research was limited to cultural approaches in learning by teachers, local leaders in running the local government, and company leaders in advancing companies, while our research describes a cultural approach in the form of the use of the lonto leok cultural moral values (LLCMV), from the Manggarai community, West Flores, Indonesia, as a standard of character values in schools. Besides, it describes the steps in applying the lonto leok culture approach by the school principal to optimize the implementation of a CESP at one of the junior high schools in West Flores, Indonesia.

The reason principals use LLCMV as a standard for character values in schools is because the LLCMV has become the norm and the values that underpin the life order of teachers, employees, students, parents, and the community (Tapung et al. 2018). Besides, motivated by the environmental conditions of schools and communities who hold fast to cultural values and norms, and coupled with an adequate headmaster's knowledge of the culture of lonto leok, encouraging school principals to adopt the LLCTDA in carrying out their roles is essential. Furthermore, the principal unites the cultural approach with the transformational leadership model conceptualized by Podsakoff et al. (1990) and Leithwood and Jantzi (1999). The dimensions of transformational leadership are combined with the dimensions of teaching lonto 
leok culture-namely, articulate the vision, provide intellectual stimulation, offer individual support, describe professional practices and values, show high-performance expectations, and develop structures to encourage participation in school decisions. Meanwhile, to assess the effectiveness of the LLCTDA, it is assessed in comparison with the national cultural dimension of Hofstede (1984), which includes power distance, avoidance of uncertainty, individuality, and masculinity.

Based on the literature review of lonto leok's policies and cultural approaches by the principal in supporting the implementation of education strengthening, the focus of our present study is two-fold:

1. To what extent are moral and cultural values of lonto leok used as a standard of education character by the school principal?

2. What are the steps of transformational leadership based on the approaches of teaching lonto leok culture dimensions by the school principal?

\section{Literature Review}

\section{The Importance of Character Education Based on Cultural Values}

Education is a conscious effort to build the science of knowledge and the consolidation of values in students (Obanya 2005). Culture is a system of values, norms, and ethical, spiritual life, thinking, and behavior that is changeable because of communication with other people in living together and the relationship with the natural world (House et al. 1999; Nieto 2008). Character is the existence of a human personality that is formed through the deposition of virtue values to shape behavior (CEP 2002). CES is a pedagogical activity that unites hearts, feelings, minds, and bodies, that is carried out through collaboration with schools, parents, and the community (Ministry of Education 2017). Thus, education and moral teaching are essential to shape the moral, social, and spiritual lives of the students, as the basic power to build a better life in the future (Lickona 1996; UNESCO 2012).

The development of individual character can only be done in a particular social and cultural environment (Nieto 2008). Education as a cultural mission must be able to process cultural heritage; help students take on social roles and teach using those roles; expand the students' identity into a wider cultural sphere; develop and maintain cultural competence; develop a critical awareness of the social order challenging the status quo; and become a source of social innovation (Ladson-Billings 1992).

\section{Lonto Leok Culture Wisdom from the Manggarai Community, West Flores, Indonesia}

Lonto leok is a cultural heritage value for the life of the Manggarai community. The word lonto leok comprises two words-lonto means sitting, and leok means circular. So the word lonto leok means the form of sitting in a circle when gathering together, including traditional rituals involving many people (Verheijen 1967). Lonto leok is inspired by the form of a traditional Manggarai house (Mbaru Gendang) in the form of a circle on the roof leading to a height in the form of a cone, and agricultural land (lodok) in the form of a spider's nest, which leads to the center (Sutam 2014). The core meaning of lonto leok culture explains the philosophy of life that contains moral values that shape the character of the Manggarai community, and the school community in particular.

The cultural symbol of lonto leok inspires Manggarai people to idealize a harmonious life and a spiritual life. Harmony in life is formed through the appreciation of moral values, such as: (1) democracy, which prioritizes openness, respect, and humility in accepting the opinions of others, discussions that give priority to the ethics of speaking, and every decision making takes 
into account the interests of many people; (2) unity, which emphasizes a harmonious life, harmony, respect for differences, avoidance of conflict, establishing open communication without discrimination; (3) peace, which demands a peaceful, calm life, avoids hostility, does not demean others, does not seek fault with others, and does not speak of the ugliness of others; (4) love, which is shown in the attitude of accepting others with all its limitations, caring for the poor, giving assistance to people who experience shortages, being willing to sacrifice for the happiness of others, doing something that does not harm others; (5) justice, which is shown through selflessness, respecting the rights of others, treating others equally before the rules and laws, not taking the rights of others; (6) honesty, applied through an open attitude, speaking according to facts, not being manipulative, admitting mistakes, admitting the strengths of others, not transferring blame on others; (7) hard work, as evidenced by enthusiasm at work, not giving up, being responsible for work, and valuing work; (8) hospitality, which is shown through the attitude of accepting others, being open in communication, as well as speaking politely and ethically, and not being quick to judge the mistakes of others (Sutam 2014; Tapung et al. 2018).

Other researchers have investigated the meaning of the LLCMV. Erb (2005) examines the role of the political elite in reforming the image of local culture, including one of the lonto leok cultures, in building a "New Manggarai" to support decentralization and democratization policies in the post-1998 reform era. Sutam (2014) examines the impact of the lonto leok culture approach in traditional ceremonies like Manggarai marriage. Nggoro (2013) examined the effectiveness of group learning for elementary students based on the lonto leok culture. These previous studies focus on the inculcation of democratic values in learning and the use of democratic aspects by community leaders. In contrast, our research focus is on the principal's policy of exploring, discovering, and developing seven aspects of the LLCMV, which are then jointly determined (teachers, employees, parents, school committees, community leaders, traditional leaders, and school supervisors) as standard values of the main characters in schools, as a school branding.

\section{The Principal's Transformational Leadership in Lonto Leok Culture-based Schools}

Principal leadership behavior implies changes and school progress, in the form of teacher work quality, the effectiveness of school programs, and student achievement (Leithwood and Jantzi 1999). The effectiveness of principals' leadership is related to local cultural conditions (Spreitzer, Perttula, and Katherine 2005). Different cultural characteristics require different transformational leadership approaches. The culture emphasizes the sense of identity and "ownership" of certain groups, through norms, rituals, values, beliefs, and language (Ferraro 1998). Different cultural characters in society require adaptive TLB. Thus, culture can influence the concepts, styles, and practices of transformational leadership (Hofstede 2001).

In optimizing the implementation of CES, principals used the TLB approach developed by Podsakoff et al. (1990) and Leithwood and Jantzi (1999), and explained by other researchers. CES is also supported by the LLCTDA in the Manggarai community through the following steps. First, the school principal encourages the progress of the school, based on the vision, mission, and common goals, through the LLCTDA in the form of "tatong” (striving for progress and better change) (Leithwood and Jantzi 1999; Sutam 2014). Its philosophical meaning is that "everything in the world is constantly changing and that nothing remains in its initial state." The transformative value of teaching this culture supports the behavior of leaders who work professionally for the betterment and change of education by the shared vision and mission (Hofstede 1993; Sutam 2014). Second is intellectual stimulation, supported by the LLCTDA in the form of "toing" (life lesson). This transformative value of cultural teaching supports the behavior of leaders who provide stimulation of knowledge to followers, through guidance, training, and further study, so that followers can be creative and innovative in teaching activities 
(Podsakoff et al. 1990; Bass and Steidlmeier 1999; Sutam 2014). Third, previous studies offer individual support and is supported by the LLCTDA, in the form of "toto nai bakok" (caring). Its philosophical meaning is that "every person must be sincere to support and love another person." This transformative value of cultural teaching supports the behavior of leaders who recognize and value contributions, empathy, and respect for the needs of teachers and students (Spreitzer, Perttula, and Katherine 2005; Sutam 2014).

Fourth, professional practice and values are supported through the LLCTDA of "titong" (giving guidance in life). Its philosophical meaning is that "everyone must have responsibilities in life." The transformative value of this cultural teaching supports the behavior of leaders who work openly, transparently, accountably, and participative so that educators are motivated to be involved in supporting the work of leaders. (Podsakoff et al. 1990; Sutam 2014). Fifth, highperformance expectations are also used. The supporting LLCTDA are "tatang or titing" (empowering the potential of others). Its philosophical meaning is that "every person needs to help and support the other person.” The transformative value of this cultural teaching supports the behavior of leaders who provide inspirational motivation, through behavior that trusts the teacher, appreciates the work of the teacher, allows the teacher to take part in training, thereby encouraging the professionalism of the teacher's work. (Yammarino, Dubinsky, and Spangler 1998; Sutam 2014). This dimension opposes the culture of conformity, nepotism, and loyalty. Sixth, is the development of structures for participation. The LLCTDA under this leadership behavior is "bantang cama reje leleng" (cooperation/joint involvement). Its philosophical meaning is that "all humans need the presence of other humans in life." This transformative value of cultural teaching supports the behavior of leaders who involve parents and the community in supporting school programs (Leithwood and Jantzi 1999, 456). The LLCTDA emphasizes gender alignments and opposes individualism and masculine dominance in traditional culture (Hofstede 1993; Sutam 2014).

\section{Methodology}

This study used a qualitative and analytic descriptive research design. This research design is a research procedure used in various scientific disciplines, including education, psychology, and social science (Creswell 2009; Yin 2017). This research method is motivated by the recognition that schools are complex social organizations. To describe this complexity, the design not only describes how education takes place or what factors influence it but also needs to describe more deeply the process of school policymaking, the parties involved in policymaking. In addition, we described the steps of coordinatingwith the principal in implementing policies in the form of activity programs through the lonto leok cultural approach pattern. Regarding the planting of lonto leok cultural values, Tapung et al. (2018) have used ethnographic methods and research development. This study did not produce significant results, because the authors explored primary data by interviewing elders and cultural experts, while lonto leok cultural values were used in classroom learning. Here we find differences in usefulness and place, between the parties interviewed and those who use the values of lonto leok culture.

Both types of research involve naturalistic data or natural settings. Qualitative research is more holistic in collecting data from various sources, in the form of opinions, perspectives, and attitudes that provide in-depth information related to the process, determination, lonto leok values as the standard values of the main characters in the school, and the transformational leadership approach of the principal strengthened through the lonto leok teaching approach.

The presence of researchers is a measure of success in exploring the focus of research. The researcher acts, with the help of others, as a key instrument in collecting data from people actively involved, such as; school principal, teacher, employee, student, parent, school committee, supervisor. Additionally, interviews with indigenous elders and cultural thinkers/activists were done (Miles, Huberman, and Saldaña 2014). The sampling technique in 
this study, namely purposive sampling, was applied using the chimney technique. The data collection process starts from broad data collection, then narrows according to the focus of the study.

The source of this research data is from primary data collected from key informants in the form of words or verbal words, and from secondary data in the form of documents, as a complement to primary data (Yin 2017). The selection of informants was carried out with several techniques; first, purposive sampling, selecting informants who mastered the information in-depth, reliable as a valid data source. Data sources used in the study comprised two groups, firstly cultural expert groups (three traditional elders, and three cultural thinkers/activists), which spread in Manggarai Regency, East Manggarai Regency, and West Manggarai Regency. The purpose of collecting data from cultural experts is to check the truth between the lonto leok culture material presented and implemented in schools. The second group is the participants in the school environment (school principal, teacher, employee, student, parent, school committee, supervisor). The participants were chosen to attain information related to the main reasons schools included the local cultural moral values of lonto leok as the school branding, and to obtain information about the practice of school principal transformational leadership based on the teaching dimension of lonto leok. These two research focuses were investigated and described to prove that the schools have implemented character education optimally. The interview is used to reveal the participants' point of view in interpreting people, phenomena, organizational activities, feelings, motivation, and acknowledgments toward the research focus (Miles, Huberman, and Saldaña 2014).

The conditions for the election of indigenous elders are as follows; aged 65-80 years old, understanding the broad and profound culture of lonto leok, often invited by the Regency Government to provide materials for lonto leok, live in traditional houses (mbaru gendang), and still actively lead traditional rituals. Election requirements for cultural thinkers/activists: aged 65-80 years old, held the post of indigenous elder, has a broad and deep knowledge of the culture lonto leok, often invited by the local district government to provide materials about the culture lonto leok.

Secondly, school components directly involved amounted to sixty-eight informants, namely; headmaster (1); vice-principal (1); coordinator of curriculum work team (1); coordinator of student affairs work team (1); coordinator of community relations work team coordinator (1); senior teachers representing grades VII, VIII and IX teachers (15); class caregivers (6); teacher guidance and counseling (3); religious teachers (4); teachers in arts and culture (2); teacher developing interests and talents (2); and people representing students in class VII, VIII, IX (12). Representing the District Education Office (school supervisor and head of the secondary education sub-sector) as monitors (3), staff members of the school committee (6), and people from the parents' side of the student (10). Second, snowball sampling, looking for information continuously from one informant to another informant, so that the data collected is more and more complete and in-depth and stops when the data got is considered to be saturated. Related to events or activities at school, we make direct observations.

To analyze the data, we organized the interview data, field notes, and other materials and tried to document any emerging themes in those data (Cresswell 2009). The analysis activity is continued by analyzing data, arranging, dividing into units, synthesizing, looking for patterns, finding what is meaningful and what is researched and reported systematically. At this stage, data analysis is carried out and used in such a way as to get the truth of the data used to answer the focus of this research. The inductive method is used to manage the qualitative data of this study. The inductive method allows the arrangement of data in the form of data condensation, in the processes form of selecting, focusing, simplifying, abstracting, and/or changing the data that appears in full research from written field notes, interview transcripts, and documents. Then the data is presented, which allows drawing conclusions and actions. We draw temporary 
conclusions based on matrices that have been made to find patterns, topics or themes according to the focus of the study (Miles, Huberman, and Saldaña 2014).

The data validity in this research used several meansurements as follows: first, credibility measure. The purpose of data credibility was to prove the data suitability with the facts in the research (Miles, Huberman, and Saldaña 2014). To establish the data validity, the researchers used the following inspection techniques: 1) extending involvement, thus allowing the credibility level to be increased in the data collected. By extending the involvement, the accuracy of information was obtained, and we formed a subject trust. Therefore, the researchers extended the participation that occurred in the research background. 2) The persistence of observation meaning that the researchers looked for and found the characteristics and elements in situations relevant to the problem being studied. 3) Triangulation helped the data checking by comparing it to other data. We carried this out in several phases: (a) source triangulation by (1) comparing observation data with interview data, (2) comparing what they said in public with what they said privately, (3) comparing what people said about the research situation with what they said all the time, (4) comparing one's circumstances and perspectives with other's views, and (5) comparing the results of interviews with the contents of related documents. Phase (b): The triangulation method was carried out by checking the credibility level in the research findings based on several data sources. Phase (c): Theory triangulation compared facts with one or more theories as a comparative explanation (Miles, Huberman, and Saldaña 2014). 4) A peer examination was performed through discussion with a peer. 5) Negative case analysis, by collecting examples of cases that were not based on patterns and trends of information that had been collected and used as a comparison. 6) examining members, to check whether the data recorded and interpreted by the researchers was appropriate and key informants recognized the truth. Second, transferability. This technique requires researchers to report the results of their research as carefully as possible and refer to the focus of the study. The findings are not part of the detailed description, but the interpretation is in the form of detailed descriptions with all kinds of accountability based on real events (Miles, Huberman, and Saldaña 2014).

Thirdly, dependability: Dependency or dependency audit is carried out by presenting an auditor (supervisor) to check the raw data that has been collected by researchers, data reduced, and the results of data analysis, data reconstruction, and synthesis results, notes about the course of research material related to the intent and desires including research proposals, and information on instrument development including the format of interview questions, observations, and documents (Creswell 2009). Fourth, confirmability: The examination of certainty criteria comprises several steps. First, the auditor needs to find out whether the research findings come from the data. Second, the auditor determines whether conclusions are drawn and derived from the data by taking into account the accuracy of the researcher, and whether they are based theoretically, and whether they over-emphasize the a priori researchers' knowledge in conceptualizing the findings. The criterion of study certainty relates to the extent to which the data and its interpretation are based on the data rather than merely as a construction the effort of the researcher himself. (Miles, Huberman, and Saldaña 2014).

\section{Findings}

Based on data collection from key informants, several points of findings are related to the principal's policy in the process of determining the standard values of the main characters in schools that are extracted from the LLCMV. Furthermore, the steps of the transformational leadership role of the school principal are supported by the LLCTDA, starting from the planning, implementation, and evaluation of CESP. 


\section{Standard of Character Values in School}

The analysis of this study portrayed that lonto leok is one of the cultural heritages that contains moral values and norms of community life and guidance for a leader in applying the LLCTDA. In tracing the history of the Manggarai people in the past, traditional leaders named "Tua Golo" (Tua= elders; Golo= region) and King (Manggarai: Dalu) as community leaders practiced the LLCTDA using the transformational leadership implementation. Integrating transformational leadership models and cultural dimensions are typical of the Manggarai leadership model. The LLCTDA that support TLB includes; a) "tatong," which emphasizes the desire to change towards future progress, b) "toing" is the giving of teachings on how to fight for a better life, c) "titong" is an effort to guide others to respect the values and norms of life together, d) "tatang or titing" is an effort to develop the potential of others to be useful for life, e) "toto nai bakok" is an expression of one's caring for others sincerely, f) "bantang cama reje leleng" is the desire to build cooperation with other people.

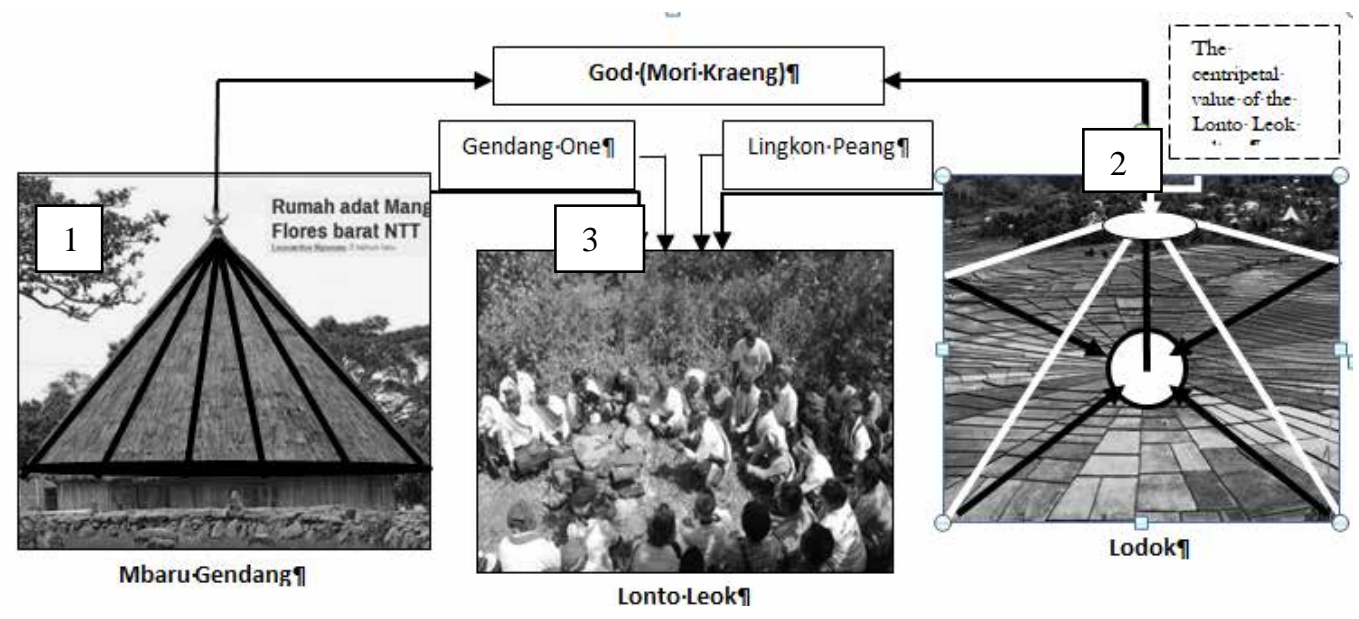

Figure 1: Symbol of Lonto Leok

Source: West Manggarai District Tourism Office

Figure 1 portrays the life philosophies of the Manggarai people, symbolized by a traditional house (mbaru gedang) in the form of a circle that leads to the top forming a cone. This figure explains plans of human activity that are taught together at home and the goal is that each activity brings the safety of the Highest (Mori Kraeng). Figure 1 also displays one philosophy of life which is agricultural land (lodok) in the form of cobwebs. The philosophy means that all human activities on earth always move toward the center of life (centripetal), which is the Highest (Mori Kraeng). Lastly, Figure 1 shows that all human activities need to be regulated, directed, and guided by a leader. The presence of a leader is believed to be a manifestation of the presence of the Supreme Being (Mori Kraeng) that guides fellow human beings to live in the regularity of values and norms to create a harmonious life and gain salvation after death.

Lonto Leok cultural values fight for the safety of life after death. Salvation is obtained through moral actions, such as (a) democracy in fighting for mutual rights, the opportunity to express their thoughts, and freedom in the fight for life; (b) unity, which is shown in harmony in living together, prioritizing unifying and non-discriminatory actions; (c) peace, through tolerance and mutual respect in differences; (d) love, which is shown in empathy, compassion, and mutual respect; (e) fairness, which is fought in the form of actions that treat others equally and with dignity; (f) honesty, in carrying out personal and group lives; (g) hard work, to fight 
for a decent life; (h) hospitality in accepting differences, and accepting others with their strengths and weaknesses. In education, moral values depicted in lonto leok are the standard for student character values development. These character values become the school's branding and are strengthened by the idiom go' et as the driving and unifying force of mind, heart, and action.The following table is a comparison of the main character values of Indonesian national education and the values of Lonto Leok character.

Table 1: Values of National Main Characters and Character Values of Lonto Leok

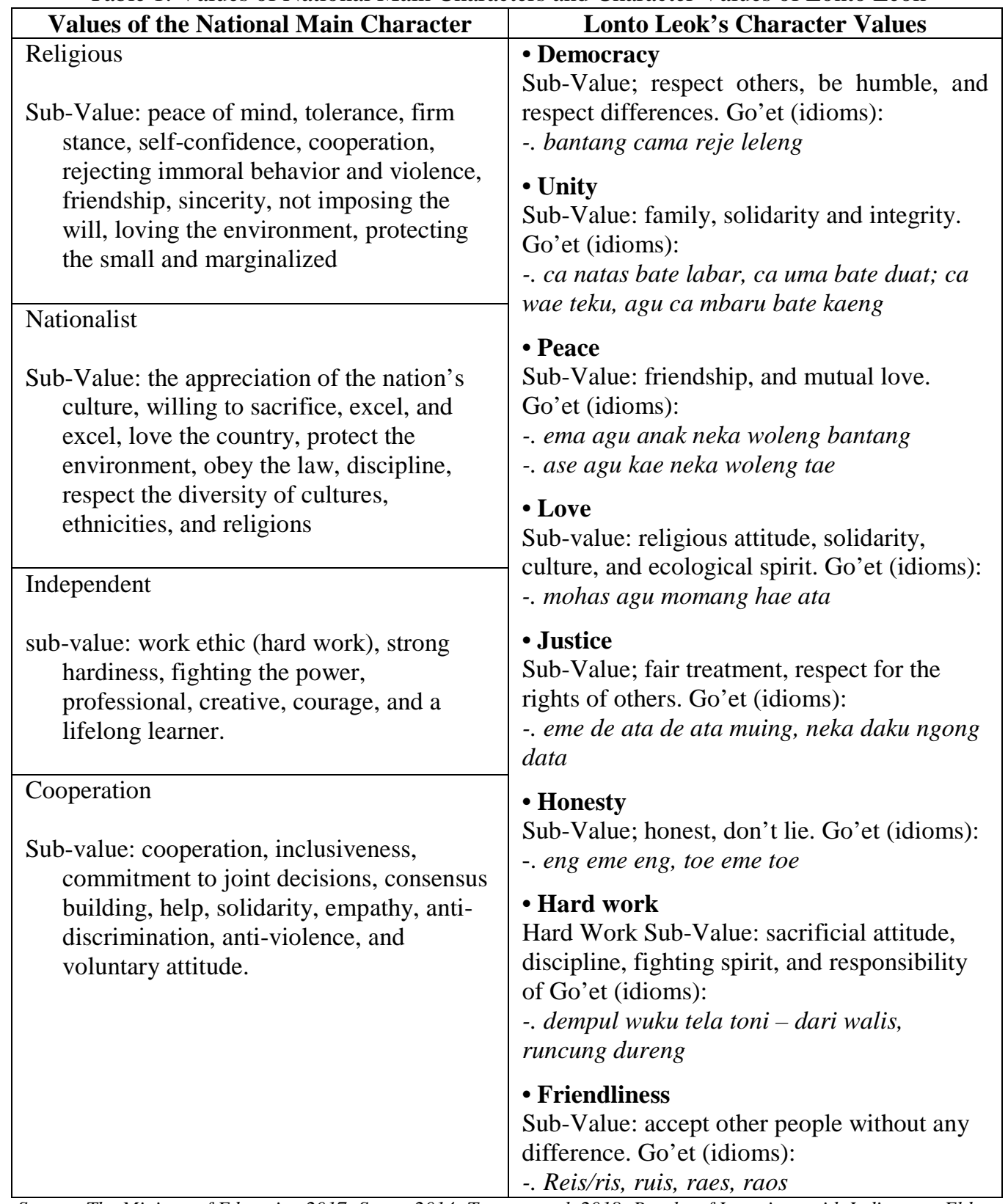

Source: The Ministry of Education 2017; Sutam 2014; Tapung et al. 2018; Results of Interviews with Indigenous Elders 


\section{Steps of the Principal's Transformational Leadership}

In the second discovery, we collected data from three types of thinkers/cultural activists: headmaster (1), vice-principal (1), coordinator of curriculum work team (1), coordinator of student affairs work team (1), coordinator of community relations work team coordinator (1), senior teachers representing grades VII, VIII and IX teachers (15), class caregivers (6), teacher guidance and counseling (3), religious teachers (4), teachers in arts and culture (2), teacher developing interests and talents (2), and people representing students in class VII, VIII, IX (12). Representing the District Education Office (school supervisor and head of the secondary education sub-sector) as monitors (3), staff members of the school committee (6), and people from the parents' side of the student (10). Based on the information collected, we found that the school surveyed had applied the lonto leok value as a standard for character education. The success of the school in applying the lonto leok value, supported by the principal's transformational leadership strategy, is reinforced by the LLCTDA.

\section{Steps Program Planning}

One factor supporting the Manggarai people to uphold the values of a harmonious, peaceful, and spiritual life is the presence of a leader. Since royal times, a King (Dalu) has made the teaching of lonto leok a guideline. The dimension of lonto leok's teaching guides the mind, heart, and actions of the community. Likewise, with the traditional/cultural leader called Tua Golo/Tua Gendang (Indigenous Elders), in directing the head of the clan (tua panga) and other members of the tribe, uses dimensions of lonto leok teaching as a doctrine that brings together all members of the tribe. The teaching dimension of lonto leok is used by the leaders in various social institutions, including the education sector. The dimensions of teaching lonto leok are transformative dimensions of leadership values because they are not time-limited; and practiced in various spheres of life, according to the background of the ethnicity, religion, race, class, and culture of the people who use them.

In time, it was practiced in several schools in Manggarai-Flores, including one Junior High School in Manggarai Regency, West Flores, Eastern Indonesia. In the CESP, the steps of the lonto leok activity by the principal are as follows. (a) establish networks of collaboration between schools, government, parents, school committees, and traditional leaders. In the lonto leok meeting, the school principal allowed two traditional leaders to present the material on the lonto leok value. In the discussion session, the principal assigned the discussion participants to select and include the moral values of the lonto leok culture as a standard for character values in schools, and these values became the school's branding. (b) The principal formed a special team comprising three senior teachers representing the school, one traditional leader, one person from the government (education department of youth and sports), and two people representing parents to formulate the vision, mission, and objectives of character education. (c) The principal assigns each work team to design a lonto leok-based CEPS that includes (1) self-development activities; (2) class activities; (3) school environment; and (4) society. Table 2 illustrates a comparison of the planning activities by general principals in Indonesia and the planning steps of the principal based on the lonto leok culture. 
Table 2: General School Principal Strategic Steps in Indonesia and Lonto Leok Based School Principal Strategic Steps in Manggarai Community, West Flores - East Indonesia

\begin{tabular}{|c|c|c|}
\hline \multicolumn{3}{|c|}{ Strategic Steps of School Principals in Program Planning Activities } \\
\hline Principal strategic steps & $\begin{array}{l}\text { Strategic steps for principals in } \\
\text { general }\end{array}$ & $\begin{array}{l}\text { The strategic steps principals } \\
\text { combined with the teaching of } \\
\text { cultural values lonto leok }\end{array}$ \\
\hline $\begin{array}{l}\text { Involving all parties, } \\
\text { internal schools, parents, } \\
\text { school committees, school } \\
\text { superintendent, traditional } \\
\text { leaders in setting the } \\
\text { standard value of the main } \\
\text { characters in school }\end{array}$ & $\begin{array}{l}\text { - Using common character values, } \\
\text { and not yet integrated with local } \\
\text { cultural character values } \\
\text { - Principals use their own policies } \\
\text { in determining the school's } \\
\text { character values }\end{array}$ & $\begin{array}{l}\text { - Setting standards of school } \\
\text { character values derived from the } \\
\text { cultural values of Lonto Leok } \\
\text { culture } \\
\text { - Involving various stakeholders in } \\
\text { determining the school's character } \\
\text { values }\end{array}$ \\
\hline $\begin{array}{l}\text { Formulating the } \\
\text { achievement of the vision } \\
\text { and mission to become a } \\
\text { common goal in line with } \\
\text { the strengthening of } \\
\text { character education }\end{array}$ & $\begin{array}{l}\text { Contextually, the formulation of } \\
\text { the vision, mission, and objectives } \\
\text { of the school are not integrated } \\
\text { with the condition of the school } \\
\text { and does not blend with the moral } \\
\text { values of the local culture }\end{array}$ & $\begin{array}{l}\text { Contextually, the formulation of the } \\
\text { vision, mission, and goals of the } \\
\text { school is in accordance with the } \\
\text { conditions of the school and } \\
\text { integrates with the moral values of } \\
\text { the local culture }\end{array}$ \\
\hline $\begin{array}{l}\text { Program to strengthen } \\
\text { character education }\end{array}$ & $\begin{array}{l}\text { Not yet integrated with the school } \\
\text { curriculum, so it cannot be } \\
\text { distinguished between school } \\
\text { activities in general and activities } \\
\text { specifically strengthening character } \\
\text { education }\end{array}$ & $\begin{array}{l}\text { Strengthening of character } \\
\text { education into the main part of the } \\
\text { school curriculum, so that it blends } \\
\text { with the rest of the school activities }\end{array}$ \\
\hline
\end{tabular}

\section{Steps in Program Implementation}

The implementation of the lonto leok program in the school is set for one semester (6 months). In one semester it is divided into two stages. Each phase takes three months, followed by a midterm evaluation. The results of the midterm evaluation are used to improve the implementation of the program in the second stage, and subsequently an end-of-semester evaluation is performed. In the lonto leok program implementation, the principal always directs the teachers and employees by providing aspects of teaching lonto leok culture that contain moral values. This is done in a meeting every morning in the teacher's room before teaching begins. This meeting discusses some aspects for teaching enhancement, such as solicitation, encouragement, enlightenment, criticism, and feedback for practice. Supported by philosophical words in the form of go' et (idioms), the aim is to move thoughts, hearts, intentions, and actions together. The dimensions of lonto leok teaching that support the effectiveness of the principal's role in optimizing the implementation of CES are presented in Table 3. 
Table 3. The Six-Point The LLCTDA Which Applied by the Principal

\begin{tabular}{|c|c|c|}
\hline $\begin{array}{l}\text { The dimensions of } \\
\text { teaching Lonto } \\
\text { Leok culture }\end{array}$ & (Go'et/idioms) & $\begin{array}{l}\text { Values Model of Lonto Leok } \\
\text { Culture Lessons by the Principal }\end{array}$ \\
\hline $\begin{array}{l}\text { Tatong (strive for } \\
\text { progress and better } \\
\text { change) }\end{array}$ & $\begin{array}{c}\text { anggom taung; nipu riwu, } \\
\text { ongko do (unity / } \\
\text { togetherness for mutual } \\
\text { progress) }\end{array}$ & $\begin{array}{l}\text { Striving to achieve progress and } \\
\text { change in accordance with the } \\
\text { demands of the vision, mission, and } \\
\text { purpose together with a more optimal }\end{array}$ \\
\hline Toing (life lesson) & $\begin{array}{c}\text { lewing ngombek, kebor } \\
\text { léwé (provide knowledge } \\
\text { so that all can do their } \\
\text { work) }\end{array}$ & $\begin{array}{l}\text { Give freedom and trust to teachers, } \\
\text { employees at work, so they can } \\
\text { develop work innovatively, creatively } \\
\text { in exploring and finding new ways to } \\
\text { overcome problems in learning }\end{array}$ \\
\hline $\begin{array}{l}\text { Toto Nai Bakok } \\
\text { (caring) }\end{array}$ & $\begin{array}{l}\text { neho waé nggéreng ati agu } \\
\text { nain (give support to others } \\
\text { sincerely and empathically) }\end{array}$ & $\begin{array}{l}\text { Give an appreciation of the work of } \\
\text { teachers through praise, attention to } \\
\text { the needs of teachers, empathy and } \\
\text { personal respect and competence they } \\
\text { have. }\end{array}$ \\
\hline $\begin{array}{l}\text { Titong (giving } \\
\text { guidance in life) }\end{array}$ & $\begin{array}{l}\text { T’oing agu wahéng (give } \\
\text { instructions and correct } \\
\text { teaching) }\end{array}$ & $\begin{array}{l}\text { Give inspirational motivation and } \\
\text { stimulation of knowledge to teachers } \\
\text { in order for them to work } \\
\text { professionally in seeking maximum } \\
\text { work and exceeded the planned target }\end{array}$ \\
\hline $\begin{array}{l}\text { Tatang or Titing } \\
\text { (empowering the } \\
\text { potential of others) }\end{array}$ & $\begin{array}{l}\text { Kudut kantis ati, cengka } \\
\text { lemas, huru nuk, helu nai } \\
\text { (Empower morale in order } \\
\text { to achieve maximum } \\
\text { results) }\end{array}$ & $\begin{array}{l}\text { Provide stimulation of knowledge to } \\
\text { teachers, employees to build a work } \\
\text { culture so that progress and change } \\
\text { can be better achieved }\end{array}$ \\
\hline $\begin{array}{l}\text { Bantang Cama Reje } \\
\text { Leleng (cooperation / } \\
\text { joint involvement) }\end{array}$ & $\begin{array}{l}\text { Ipung ca tiwu neka woleng } \\
\text { tombo, (fighting for mutual } \\
\text { interests through } \\
\text { cooperation) }\end{array}$ & $\begin{array}{l}\text { Build the spirit of cooperation with } \\
\text { various parties so that all parties } \\
\text { participate in advancing better school } \\
\text { programs }\end{array}$ \\
\hline
\end{tabular}

Source: Sutam 2014; Tapung et al. 2018; Interviews with Cultural Thinkers/Activists, School Components, Community Groups

Referring to the six aspects of the lonto leok teaching dimensions presented in Table 3 , in optimizing the program of character education strengthening in schools, the strategic steps of the principals are as follows.

(a) Designing four forms of CESP; (1) activity personal development, (2) activities in the classroom, (3) activities in school culture, and (4) activities in the community environment. The four forms of character education strengthening activities are implemented through two forms of strategic steps, namely the lonto leok phase, which aims to coordinate team work in accordance with their competencies; and the phase of socializing the types of activities so that all teamwork corresponds to job duties.

(b) The first and second stages of lonto leok activities are carried out at the beginning of the school year, while the third and fourth stages of lonto leok are arranged every three months in one semester. 
The principal's strategic steps in implementing activities based on LLCTDA are explained in Table 4.

Table 4: Form of Program and Strategic Steps of School Principals in the Implementation of Activities

\begin{tabular}{|c|c|c|c|c|}
\hline Form of CESP & \multicolumn{4}{|c|}{ Program Activities Coordination } \\
\hline $\begin{array}{l}\text { 1. Activity } \\
\text { Personal } \\
\text { Development }\end{array}$ & $\begin{array}{l}\text { Lonto Leok 1: } \\
\text { Determination } \\
\text { and Coordination } \\
\text { of Team Work }\end{array}$ & $\begin{array}{l}\text { Model for } \\
\text { Organizing } \\
\text { Activities }\end{array}$ & $\begin{array}{c}\text { Lonto Leok } \\
\text { 2: } \\
\text { Steps in } \\
\text { Socializing } \\
\text { Program } \\
\text { Activities }\end{array}$ & $\begin{array}{c}\text { Activity } \\
\text { Implementation } \\
\text { Model }\end{array}$ \\
\hline $\begin{array}{l}\text { a) Routine } \\
\text { activity }\end{array}$ & $\begin{array}{l}\text { Cooperation } \\
\text { teamwork of } \\
\text { student affairs } \\
\text { section, } \\
\text { homeroom, and } \\
\text { subject teachers }\end{array}$ & $\begin{array}{l}\text { Selecting, } \\
\text { determining and } \\
\text { scheduling routine } \\
\text { student activities } \\
\text { at school }\end{array}$ & $\begin{array}{l}\text { Homeroom } \\
\text { teacher } \\
\text { conduct } \\
\text { socialization } \\
\text { activities } \\
\text { program for } \\
\text { students }\end{array}$ & $\begin{array}{l}\text { Clean the classroom } \\
\text { every morning, } \\
\text { arrange for the flag } \\
\text { ceremony attendant, } \\
\text { attendance, make a } \\
\text { note of student } \\
\text { violations }\end{array}$ \\
\hline $\begin{array}{l}\text { b) Spontaneity } \\
\text { activities } \\
\text { according to } \\
\text { behavioral } \\
\text { demands }\end{array}$ & $\begin{array}{l}\text { Collaboration } \\
\text { between teacher } \\
\text { guardian of the } \\
\text { student, subject } \\
\text { matter teacher, } \\
\text { teacher guidance } \\
\text { and counseling in } \\
\text { giving examples } \\
\text { and role models }\end{array}$ & $\begin{array}{l}\text { Formulate } \\
\text { guidelines for } \\
\text { student behavior } \\
\text { when in the } \\
\text { school } \\
\text { environment }\end{array}$ & $\begin{array}{l}\text { Teachers } \\
\text { guardians of } \\
\text { students } \\
\text { discuss and } \\
\text { formulate } \\
\text { together with } \\
\text { students }\end{array}$ & $\begin{array}{l}\text { Dispose of trash in its } \\
\text { place, maintain class } \\
\text { peace, do not commit } \\
\text { violence and } \\
\text { intimidation, use } \\
\text { words that are } \\
\text { ethical, speak } \\
\text { politely, be honest, } \\
\text { do not steal, do not } \\
\text { cheat, do not do } \\
\text { bullying }\end{array}$ \\
\hline $\begin{array}{l}\text { c) Modeling } \\
\text { Activities }\end{array}$ & $\begin{array}{l}\text { All teachers, } \\
\text { employees must } \\
\text { set an example of } \\
\text { good behavior in } \\
\text { the school } \\
\text { environment }\end{array}$ & $\begin{array}{l}\text { All teachers and } \\
\text { staff make a } \\
\text { memorandum of } \\
\text { understanding and } \\
\text { commitment to } \\
\text { always show good } \\
\text { behavior to } \\
\text { learners }\end{array}$ & $\begin{array}{l}\text { All teachers } \\
\text { and employees }\end{array}$ & $\begin{array}{l}\text { Have moral } \\
\text { knowledge, moral } \\
\text { feelings, and good } \\
\text { moral actions in the } \\
\text { school environment }\end{array}$ \\
\hline Principal’s TLB & \multicolumn{4}{|c|}{$\begin{array}{l}\text { Encourage and provide inspirational motivation for teachers and staff to have a } \\
\text { commitment to carry out routine, spontaneous and exemplary activities in school. } \\
\text { In addition, building solid cooperation with team work, homeroom teachers, } \\
\text { teachers so that they have the responsibility to shape the character of students. The } \\
\text { principal's strategic move is supported by the Lonto Leok cultural approach, } \\
\text { namely "bantam cama reje leleng (cooperation / joint involvement) and titong } \\
\text { (giving guidance in life) so that it works professionally and produces changes } \\
\text { beyond the targets that have been planned together. }\end{array}$} \\
\hline
\end{tabular}




\begin{tabular}{|c|c|c|c|c|}
\hline $\begin{array}{l}\text { 2. Activities in } \\
\text { the classroom }\end{array}$ & & & & \\
\hline $\begin{array}{l}\text { a) Integrated into } \\
\text { the learning } \\
\text { material }\end{array}$ & $\begin{array}{l}\text { Teamwork } \\
\text { curriculum, teachers } \\
\text { of subjects }\end{array}$ & $\begin{array}{l}\text { Lesson schedule, } \\
\text { completeness of } \\
\text { learning tools } \\
\text { (material, lesson } \\
\text { plans, syllabus, } \\
\text { rubric of student } \\
\text { behavior } \\
\text { assessment) }\end{array}$ & $\begin{array}{l}\text { cCmember } \\
\text { of teamwork } \\
\text { curriculum, } \\
\text { teachers of } \\
\text { subjects }\end{array}$ & $\begin{array}{l}\text { Classifying teachers } \\
\text { based on subject } \\
\text { groups when } \\
\text { preparing syllabi, } \\
\text { lesson plans, learning } \\
\text { materials, assessment } \\
\text { formats. Next, follow } \\
\text { the steps in the } \\
\text { learning steps, } \\
\text { introductory } \\
\text { activities, core } \\
\text { activities, and closing } \\
\text { activities. }\end{array}$ \\
\hline $\begin{array}{l}\text { b) Management } \\
\text { of class } \\
\text { activities }\end{array}$ & $\begin{array}{l}\text { Curriculum } \\
\text { teamwork, } \\
\text { teamwork, student, } \\
\text { teacher guardian of } \\
\text { the student, the } \\
\text { teacher of subjects, } \\
\text { discipline guidelines } \\
\text { learners }\end{array}$ & $\begin{array}{l}\text { Arrange seating } \\
\text { students, } \\
\text { explaining the } \\
\text { rules of behavior } \\
\text { of students while } \\
\text { attending classes, } \\
\text { noted the } \\
\text { violation of } \\
\text { learners when } \\
\text { learning } \\
\text { activities, filling } \\
\text { points violations } \\
\text { and impose } \\
\text { sanctions and } \\
\text { prizes to students } \\
\text { who commit } \\
\text { offenses and who } \\
\text { did not foul, do } \\
\text { the mentoring and } \\
\text { coaching to } \\
\text { participants } \\
\text { troubled protege }\end{array}$ & $\begin{array}{l}\text { Tteachers } \\
\text { guardians of } \\
\text { students and } \\
\text { students }\end{array}$ & $\begin{array}{l}\text { Listening to teaching } \\
\text { when the teacher } \\
\text { presents the subject } \\
\text { matter, respecting the } \\
\text { thoughts of peers in } \\
\text { the discussion, being } \\
\text { polite when asking } \\
\text { questions, creating a } \\
\text { pleasant classroom } \\
\text { environment, peer } \\
\text { learning activities, } \\
\text { giving punishment } \\
\text { when violating and } \\
\text { rewarding if obedient } \\
\text { and disciplined }\end{array}$ \\
\hline $\begin{array}{l}\text { c) Steps of } \\
\text { learning activities }\end{array}$ & $\begin{array}{l}\text { The school principal } \\
\text { and curriculum } \\
\text { teamwork regulate } \\
\text { the schedule of } \\
\text { learning supervision } \\
\text { activities. } \\
\text { Furthermore, the } \\
\text { principal conducts } \\
\text { supervision of } \\
\text { learning both } \\
\text { personally and in } \\
\text { groups of subject } \\
\text { teachers }\end{array}$ & $\begin{array}{l}\text { Uniform syllabus } \\
\text { models, plans for } \\
\text { implementing } \\
\text { learning, learning } \\
\text { activities, and } \\
\text { assessing student } \\
\text { behavior }\end{array}$ & $\begin{array}{l}\text { The } \\
\text { principal, } \\
\text { teachers } \\
\text { guardians of } \\
\text { students and } \\
\text { students }\end{array}$ & $\begin{array}{l}\text { Learning activities } \\
\text { and supervision of } \\
\text { learning } \\
\text { accomplished in } \\
\text { accordance with the } \\
\text { demands of the } \\
\text { guidelines that have } \\
\text { been arranged }\end{array}$ \\
\hline Principal's TLB & \multicolumn{4}{|c|}{$\begin{array}{l}\text { Develop a vision of progress through professional forms of work. Furthermore, it } \\
\text { provides stimulation of knowledge so that it has broad insights into developing } \\
\text { quality learning activities. The strategic steps principals supported through a } \\
\text { dimensional approach teaching culture lonto leok that, "tatong” (strive for progress } \\
\text { and better change), "toing" (life lessons), and "titong”" (giving guidance in life), in } \\
\text { its entirety, learning activities }\end{array}$} \\
\hline
\end{tabular}




\begin{tabular}{|c|c|c|c|c|}
\hline $\begin{array}{l}\text { 3. Activities in } \\
\text { School Culture }\end{array}$ & & & & \\
\hline $\begin{array}{l}\text { a) a) } \\
\text { Extracurricul } \\
\text { ar activities } \\
\text { such as; } \\
\text { classroom } \\
\text { sports, single } \\
\text { art, and vocal } \\
\text { competitions, } \\
\text { Indonesian } \\
\text { and English } \\
\text { speech } \\
\text { competitions, } \\
\text { arts and } \\
\text { cultural } \\
\text { shows, } \\
\text { tourist visits, } \\
\text { visits to } \\
\text { cultural sites, } \\
\text { socio- } \\
\text { charitable } \\
\text { activities in } \\
\text { orphanages } \\
\text { and nursing } \\
\text { homes, scout } \\
\text { activities, } \\
\text { greening } \\
\text { activities }\end{array}$ & $\begin{array}{l}\text { Principal, } \\
\text { curriculum } \\
\text { teamwork, student } \\
\text { teamwork, } \\
\text { extracurricular } \\
\text { teamwork activities, } \\
\text { study tour } \\
\text { teamwork, art and } \\
\text { cultural performance } \\
\text { teamwork, scout } \\
\text { teamwork }\end{array}$ & $\begin{array}{l}\text { Discuss the types } \\
\text { of extracurricular } \\
\text { activities and } \\
\text { draw up a } \\
\text { schedule of } \\
\text { activities }\end{array}$ & $\begin{array}{l}\text { Team } \\
\text { coaches and } \\
\text { trainers } \\
\text { according to } \\
\text { the type of } \\
\text { activity }\end{array}$ & $\begin{array}{l}\text { Sporting } \\
\text { competitions between } \\
\text { classes and between } \\
\text { schools, the race } \\
\text { speech, competition } \\
\text { songs with the theme } \\
\text { of religious, cultural } \\
\text { and national anthems, } \\
\text { the performing arts } \\
\text { and culture in schools } \\
\text { and in the } \\
\text { community, visits to } \\
\text { historic sites, in } \\
\text { collaboration with the } \\
\text { Department of } \\
\text { Tourism and PT } \\
\text { Angkasa Pura } \\
\text { (Airport) to perform } \\
\text { cultural performances } \\
\text { for foreign tourists }\end{array}$ \\
\hline $\begin{array}{l}\text { b) Local culture } \\
\text { lessons }\end{array}$ & $\begin{array}{l}\text { Curriculum } \\
\text { teamwork and local } \\
\text { cultural subject } \\
\text { teachers }\end{array}$ & $\begin{array}{l}\text { Discuss material } \\
\text { themes about } \\
\text { Manggarai } \\
\text { culture, prepare } \\
\text { learning tools, } \\
\text { and choose a } \\
\text { place to visit to } \\
\text { conduct cultural } \\
\text { studies }\end{array}$ & $\begin{array}{l}\text { Teachers } \\
\text { Manggarai } \\
\text { cultural } \\
\text { lessons and } \\
\text { the learners }\end{array}$ & $\begin{array}{l}\text { Syllabus guide, } \\
\text { learning } \\
\text { implementation plan } \\
\text { document, teaching } \\
\text { material, learning } \\
\text { strategy guide, field } \\
\text { study format, and } \\
\text { final learning } \\
\text { assessment format }\end{array}$ \\
\hline $\begin{array}{l}\text { Principal's } \\
\text { TLB }\end{array}$ & \multicolumn{4}{|c|}{$\begin{array}{l}\text { Encourage and stimulate knowledge relating to the development of learning by } \\
\text { subject teachers. Give freedom and trust to teachers to work professionally in } \\
\text { designing creative, innovative learning in learning activities in the community. The } \\
\text { role of the principal is accomplished through the application of the lontok leok } \\
\text { cultural teaching dimension approach in the form of "toing" (teaching how to } \\
\text { overcome learning problems), and "bantang cama reje leleng (collaboration with } \\
\text { community leaders and local traditional leaders). }\end{array}$} \\
\hline
\end{tabular}




\begin{tabular}{|c|c|c|c|c|}
\hline $\begin{array}{l}\text { 4. Activities in } \\
\text { the Community } \\
\text { Environment }\end{array}$ & & & & \\
\hline $\begin{array}{l}\text { a) Lutur Lewe } \\
\text { (Study } \\
\text { together in a } \\
\text { shared home } \\
\text { environment) }\end{array}$ & $\begin{array}{l}\text { Teamwork } \\
\text { community relations } \\
\text { affairs, the affairs of } \\
\text { field studies teacher } \\
\text { teamwork, } \\
\text { teamwork student, } \\
\text { teacher assistant } \\
\text { classes, community } \\
\text { groups }\end{array}$ & $\begin{array}{l}\text { Discuss models } \\
\text { and types of } \\
\text { activities during } \\
\text { the visit to the } \\
\text { houses of the } \\
\text { people, and } \\
\text { involves the role } \\
\text { of parents in } \\
\text { conducting } \\
\text { preventive and } \\
\text { curative measures } \\
\text { in handling and } \\
\text { shaping the } \\
\text { character of } \\
\text { learners }\end{array}$ & $\begin{array}{l}\text { Student } \\
\text { Affairs } \\
\text { teamwork, } \\
\text { class } \\
\text { companion } \\
\text { teachers, and } \\
\text { teamwork } \\
\text { teachers for } \\
\text { field studies, } \\
\text { and students }\end{array}$ & $\begin{array}{l}\text { Arrange a schedule of } \\
\text { visits, guide field } \\
\text { study activities, and } \\
\text { build coordination of } \\
\text { cooperation with } \\
\text { community leaders } \\
\text { and traditional } \\
\text { leaders }\end{array}$ \\
\hline $\begin{array}{l}\text { b) Visits to } \\
\text { traditional houses }\end{array}$ & $\begin{array}{l}\text { Teamwork public } \\
\text { relations affairs, } \\
\text { student affairs } \\
\text { teamwork, } \\
\text { classroom assistant } \\
\text { teachers, community } \\
\text { leaders, and } \\
\text { traditional leaders }\end{array}$ & $\begin{array}{l}\text { Discussing the } \\
\text { model and type of } \\
\text { outreach } \\
\text { activities, } \\
\text { establish } \\
\text { communication } \\
\text { with indigenous } \\
\text { leaders (Tua } \\
\text { Golo) and } \\
\text { scheduling a visit } \\
\text { to the traditional } \\
\text { houses (mbaru } \\
\text { gendang) }\end{array}$ & $\begin{array}{l}\text { Teamwork } \\
\text { on } \\
\text { community } \\
\text { relations, } \\
\text { students and } \\
\text { traditional } \\
\text { leaders }\end{array}$ & $\begin{array}{l}\text { Stay, living and } \\
\text { studying in the } \\
\text { cultural environment }\end{array}$ \\
\hline $\begin{array}{l}\text { The Principal's } \\
\text { TLB }\end{array}$ & \multicolumn{4}{|c|}{$\begin{array}{l}\text { Establish a partnership structure professionally with cultural community groups. } \\
\text { Learn together with the culture-loving community, and learners learn to love the } \\
\text { local culture. These strategic steps are in accordance with the approach of the } \\
\text { dimensions of teaching lonto leok culture, specifically "bantang cama reje leleng } \\
\text { (studying together, discussing together, thinking together) and" titong "(guidance } \\
\text { in living together in society) }\end{array}$} \\
\hline
\end{tabular}

Source: Podsakoff et al. 1990; Leithwood and Jantzi 1999); Hofstede 2001; Erb 2005; Nggoro 2013; Sutam 2014;

Tapung et al. 2018; The Ministry of Education 2017; Interviews with Cultural Thinkers/Activists, School Components, and Community Groups

\section{Steps in Program Evaluation}

Principal's strategic steps in conducting CESP assessment and evaluation include three forms of the Lonto Leok approach:

1. Internal evaluation activities. This activity is carried out by teamwork that is responsible for carrying out the program under the class caregivers, teacher guidance and counseling teams, student affairs teacher teams, and students (contained in the third lonto leok stage). Activities at this stage: the class teacher carries out an evaluation with students regarding the assessment of violations of student behavior recorded in the student violation book. In addition, the class teacher provides an assessment of student behavior based on assessment information from the subject teacher and the teacher counseling team. Next, the class teacher builds cooperation with the team of guidance and counseling teachers to carry out together the process of personal and group guidance to students who have committed violations. 
2. The teacher accompanying the class together with the team of subject teachers and the team of counseling guidance teachers make an evaluation report to the student affairs work team and the curriculum work team. Furthermore, the student work team and curriculum conduct a joint analysis of the effectiveness of the programs that have been implemented. Next, the student affairs work team and curriculum affairs work team made recommendations for program development during the evaluation activities with the school principal, school supervisor, and students' parents.

3. In the final evaluation based on recommendations from the working team of student affairs and the affairs of the curriculum, the school principal, superintendent of schools, and parents give feedback to assess the effectiveness of programs that have been implemented. Furthermore, based on joint considerations in the final evaluation meeting, the principal makes a decision whether the program that had been implemented was permanent or needed to be innovated, so that the effectiveness and optimization of the program would occur in the future. A summary of the program's final evaluation stages is described in Figure 2.

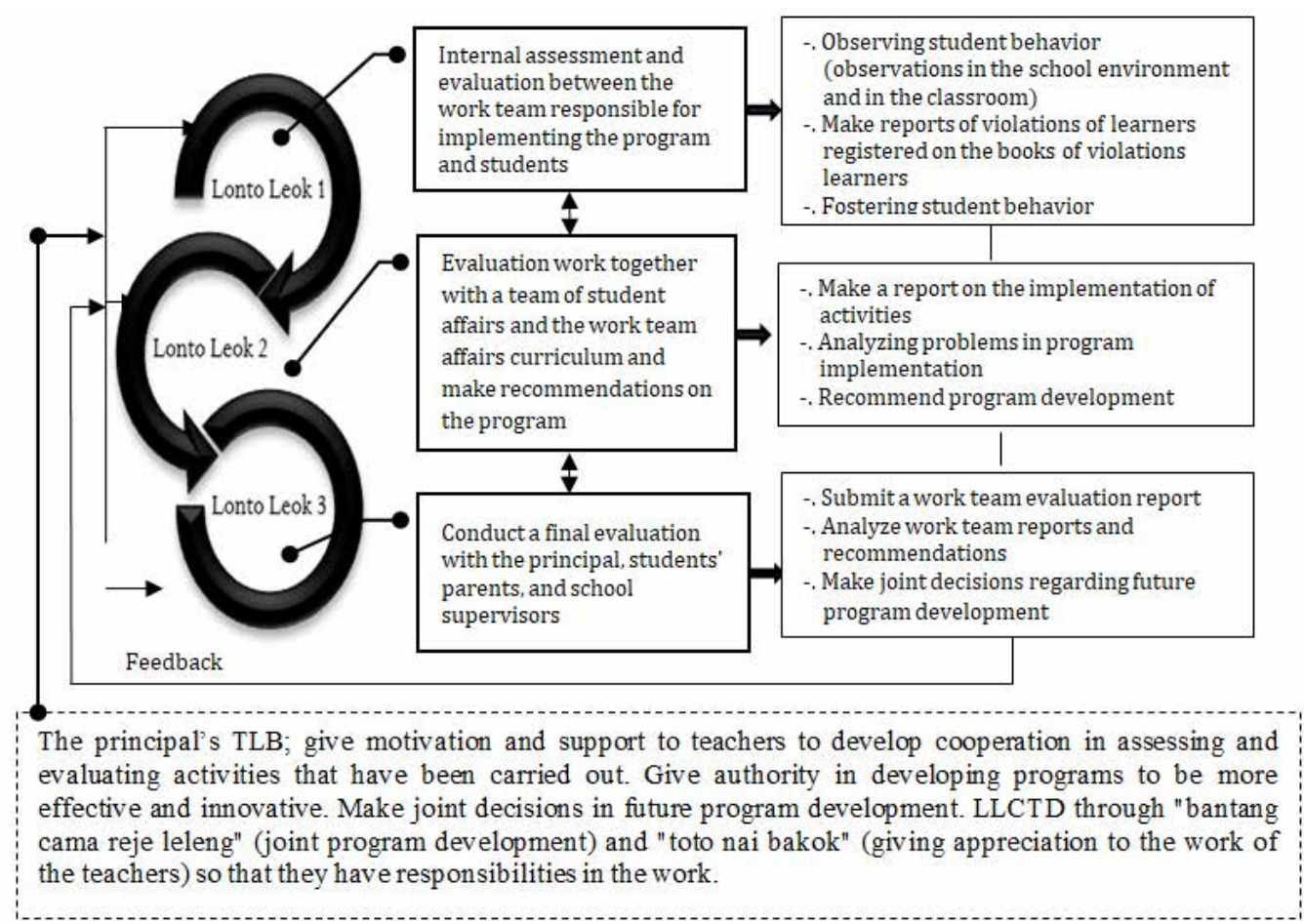

Figure 2: Stages of the Lonto Leok Program Evaluation

Source: Podsakoff et. al. 1990; Leithwood and Jantzi 1999; Interviews with Cultural Thinkers/Cultural Activists, School Components, Community Groups

\section{Discussion}

\section{Moral Values of Lonto Leok Culture as Standards of School Character Values}

Revitalization of education policy by the Ministry of Education of Indonesia is a policy that is very important in optimizing the CES program in schools. Revitalization of these policies needs to be developed based on the condition of the local cultural wealth. Using the moral values of the local culture is very important because it is very relevant to the vision, mission, and 
uniqueness of the school. In addition, by using local cultural moral values means bringing students closer to the environment that has been formed and animates their behavior.

In this context, one junior high school in Manggarai Regency, West Flores, East Indonesia, has adopted the LLCMV of the Manggarai community as the main character values in schools. The LLCMV that are used as standard values of the main characters in school are explained as follows: first, democracy, which positions the school environment as a place for the process of humanization (respecting the potential of students), personalization (student uniqueness), and socialization (self-actualization of students). Democracy class is used as a place for students to sharpen their mindset through discussion space, study and criticize new ideas and build selfconfidence (Kocoska 2009). In the school environment, the implementation of democratic values in the form of action demonstrates mutual respect, having the right to speak, to listen to each others' ideas, the freedom to express thoughts, and decision-making based on consideration of the mind together. The learning activities are demonstrated in the form of freedom of speech in discussions, respecting the minds of friends, listening to the teacher's teaching, planning class activities together, solving problems together in class, and making decisions based on mutual consideration (Koesoema 2017; Ministry of Education 2017).

Second is the aspect of unity, demonstrated in the form of a spirit of cooperation, to avoid conflict in communication, appreciate friendship in life together. In the school environment, this is demonstrated in the form of collaboration in discussion groups, feeling a sense of being one family in the educational community, and the enactment of group togetetherness and understanding between teachers, and between teachers and students, as well as having a sense of solidarity with friends (Schwartz 1994). The unity aspect is the main aspect of managing a better national and state life.

Third, the aspect of peace is demonstrated in the form of actions of respecting others, respecting differences, avoiding conflict, building harmony in living together, avoiding discriminatory actions, and having feelings of respect with others. In the lonto leok habit, putting forward the exceptions and respect for others in communication is conducted by the school principals. In the school environment, aspects of peace are demonstrated in the form of a friendly attitude with friends, mutual respect and solidarity; avoiding the use of power; accepting the other as a family; being gregarious; and creating a school atmosphere that is harmonious, peaceful, and enjoyable (Zamroni 2011). Fourth, the aspect of love is demonstrated through actions that have an aspect of Christian love. Christian values are manifested in the form of loving fellow human beings as the image of God (loving fellow human beings means loving Mori Kraeng/God). At school, the value of love is demonstrated in the attitude of accepting others with sincere hearts, respecting others, helping others who are poor, and contributing to friends who are in need. These attitudes are held by a person who has feelings of love seen from his/her relationship with God (Erikson 1958; Hegel 1807/1979), relationships with fellow human beings through the action of helping each other, the relationship with the natural environment through maintaining environmental attitudes. In the school environment, the love aspect is demonstrated in the attitude of accepting friends with their strengths and weaknesses (Lickona 2012).

Fifth, the aspect of justice is demonstrated in fair behavior dividing agricultural land as an inheritance from the ancestors to all citizens in one tribe.. In the school, the environment is demonstrated through fair treatment to all citizens of the school; according to Sudarminta (2000), fair treatment in schools is demonstrated by removing various forms of discrimination, lies, and self-interest. In addition, the application of rules must be flexible, respect students' uniqueness, and be objective in giving assessments to students (Power and HigginsD'Alessandro 2008). Sixth, the honesty aspect is demonstrated through honest attitude in behavior, not lying to people through words or actions. In the school environment, this is demonstrated by the attitudes of not cheating in exams and not bullying other people (Yaumi 2014). Seventh, the aspect of hard work is demonstrated through the passion to work to achieve 
prosperity in life and pay for children to go to school. In the school environment it is practiced in the form of a spirit of learning, a willingness to ask questions in order to gain knowledge, being humble and listening to the teacher, having an open attitude of accepting thoughts from friends, discipline in learning, and being responsible for doing school work (Koesoema 2017). Eighth, the aspect of hospitality is demonstrated through the open attitude of accepting others in living together. In the school environment, this is demonstrated through the habit of smiling, reprimanding, and greeting friends, as well as friendly attitudes with teachers and friends, and creating an atmosphere full of friendship and family in the school environment

\section{The Role of Principal Transformational Leadership in Strengthening Student Character}

Overcoming the sub-optimal implementation of CESP in Indonesia has become an important and urgent demand to improve the principal's leadership role. In the context of our study, the debate over cross-cultural management is reaffirmed, relating to specific management practices suiting a variety of cultural backgrounds. That is debated in terms of how well the application of management practices can be transferred between cultures (Hofstede 1993). At this level, culture and leadership are explained in terms of two sides of the same coin (Schein 2004). Culture and leadership cannot be understood separately: on the one hand, culture influences how organizations will interpret leadership; on the other hand, the leader's competence is the ability to get to know and work with culture. In this case, the capability to recognize the limitations of one's own culture and to describe the culture adaptive is the fundamental nature and challenge of leadership. Schein (2004) explains that a new leader replaces an existing organization if he realizes that the culture that already exists in that organization will determine and influence his leadership style. Besides, leadership in organizations is guided by pragmatic visions relating to what types of culture advance performance.

Related to research studies, specifically to optimize the implementation of CESP, it is carried out using transformational leadership style, as stated by Podsakoff et al. (1990); Leithwood and Jantzi 1999), namely: articulate and develop a vision of the future; provide the inspirational motivation that is competitive; provide support and respect for individuals (respect for individual needs, good treatment, and respect for privacy), support the development of potential through providing intellectual stimulation so that subordinates are more innovative in designing learning, developing work practically and professionally, demonstrating high performance for progress, building participatory work structures to achieve planned targets. To achieve effective work, principals use approaches based on the dimensions of local cultural teaching, especially those that emphasize the values of individualism-collectivism in accordance with the concepts put forward by Hofstede (2001). Individualism values emphasize aspects of respect for individual work, while collectivism emphasizes joint involvement in teamwork (Hofstede 2001; Sutam 2014).

In a recent study, principals at state junior high schools in West Manggarai, West Flores, Indonesia, have implemented transformational leadership behavior through an approach to the dimensions of teaching lonto leok culture from the Manggarai community. The strategic steps taken by the principal in program planning activities are: (1) involving teachers, employees, students, parents of students, school committees, school supervisors, and traditional leaders to explore, discover, and establish the moral values of lonto leok culture as standard values of character in schools; (2) forming a special team to reformulate the vision, mission, and goals of CESP; (3) coordinating and collaborating in the form of teamwork to develop CESP (Leithwood and Jantzi 2006). To support the steps of the principal, traditional leadership dimensions are used, namely individualism-collectivism developed by Hofstede (2001), in the form of rewarding individuals, and strengthened teamwork solidarity through the LLCTDA (Hofstede 2001; Sutam 2014). The LLCTDA in question are "tatong," "toing," and "bantam cama reje leleng," where the principal in the work system encourages all parties to participate in 
thinking about developing more innovative character education so that progress is achieved in accordance with the goals of the vision and mission school.

Through the development of a vision for the future, encouragement of knowledge stimulation, and the development of a structure of mutual involvement, the principal designs collegial joint planning activities to unite the sharing of knowledge resources, new ideas to achieve common goals (Groves, Kevin, and LaRocca 2011; Grant 2012; Dix 2013).

In developing and maximizing CESP, the strategic role of the principal is shown in the following steps: first, personal development activities. Optimizing these activities requires highperformance expectations and is supported by intellectual stimulation. High-performance expectations are demonstrated through the seriousness of accompanying students in routine, spontaneous, and exemplary activities. In addition, it is shown through the seriousness of accompanying and guiding students who commit violations. While the provision of knowledge demonstrated stimulation with freedom and confidence to teachers, employees develop the creativity that is innovative in dealing with learners who have problems, thus forming the character of a good learner (Leithwood and Jantzi 2006). The LLCTDA implemented by school principals is "tatang or titing" and "toing," which is an activity to empower teachers and staff competencies by giving teachers opportunities to participate in training, workshops, and further study. In addition, creating open communication, accepting new innovative ideas, and mentoring activities for students is more effective so that CESP is optimally implemented (Griffith 2004; Sutam 2014).

Second, the activities in the classroom: The role steps adopted by the principal by developing a shared vision provide inspirational motivation to teachers so that they are more responsible for teaching and professional tasks in designing learning steps. In addition, providing intellectual stimulation to teachers related to the teacher's role as a reliable teaching facilitator, so that quality learning is achieved and has the content to shape the character of students (Valentine and Prater 2011). To optimize the role of the principal, the LLCTDA used by principals is "toing” (teaching quality learning designs) and "titong” (guiding and giving work guidelines to teachers) so that learning activities are carried out well and quality. Both models of this approach implemented in a way; (1) carrying out technical guidance activities related to syllabus preparation, learning implementation plans, and learning steps that have character education content; (2) giving room for freedom and trust to teachers in implementing more creative, effective and innovative teaching; (3) provide inspirational motivation for teachers so that they can search for and discover new learning theories, and professionally apply learning theories; (4) encouraging teachers to accompany and guide students seriously and with a heart that is the power of love; (5) giving moral exemplary to teachers, employees, and students, so that they can emulate that moral example (Leithwood and Jantzi 2006; Huang and Farh 2009; Sutam 2014).

Third, activities in school culture. The positive character of school culture is explained by MacNeil, Prater, and Busch (2009); Bossworth and Hernandez (2011) as follows: (1) high motivation and learning achievement of students; (2) creation of mutually supportive cooperation between schools, the government, and the community. Therefore, in order to condition a positive school culture, the principal's strategic steps are needed, namely seeking the empowerment of teachers' competencies and developing a participatory work system. The principal's strategic steps aim to make teachers more innovative in developing a learning environment that is characterized by students. The principal's strategic steps are supported through the implementation of LLCTDA in the form of "toing" (teaching how to create a character environment), and "bantama cama reje leleng" (actively involved in supporting the creation of a characterized school environment).

Fourth, the activities in the community. Community-based character education is a model of character education that includes the community in character development activities (Tilaar 2005). The roles of the principal in establishing cooperation with the community environment 
are implemented in several ways, such as (1) creating mutual interaction and persuasive dialogue, (2) empowering students with cultural knowledge through the lutur lewe program, (3) giving authority to the work team, to establish communication with tua golo (traditional leaders), and (4) discussing visits to traditional houses (mbaru gendang) and living with cultural communities (Musana 2011; Sutam 2014). LTTCTDA which supports the role of the school principal is "bantang cama reje leleng" (mutually beneficial cooperation). Through mutually beneficial cooperation, the cultural community supports CESP, by providing opportunities for students to explore, discover local cultural wisdom to support the formation of learners' character. In addition, cultural communities are also included in school program evaluation activities, especially CESP.

In the CESP evaluation activities, the principal's strategic steps were demonstrated in a way; involves all parties in the evaluation activities, gives authority and trust to the teamwork to evaluate the program, and provides program development recommendations. The LTTCTDA implemented by the school principal is "bantang cama reje leleng" (participating) in assessing and proposing more effective and innovative program activities. In addition, it uses a "toto nai bakok" (sincere) approach to accepting constructive and innovative thinking and gives appreciation to the work of teachers (Piccolo and Colquitt 2006).

\section{Research Limitations}

The findings of this study have a novelty aspect in instilling the values of student character and the leadership practices of the principal.It is imperative since there are no schools in Manggarai regency, West Flores, Indonesia, that employ LLCMV as a standard to shape the character of the students within the school environment. Besides, no research combines the dimensions of transformational leadership of a school principal with the values of lonto leok culture. However, our study has limitations, because it only examines the moral values contained in the lonto leok culture and aspects of teaching that support the role of the leader. In addition, our time is limited by the completion of the dissertation, so our research uses only one location and one principal. It is hoped that researchers will be able to examine other aspects of lonto leok culture, which are useful for the development of education and community life.

\section{Conclusion and Implications}

In the light of the latest research, the values of lonto leok as a cultural heritage of the Manggarai community are very effective in shaping the character of students in school. This success is supported by the principal's transformational leadership role through the LLCTDA. Research can be used as a recommendation to the Indonesian National Directorate of Education and Culture, so that every school in Indonesia is given a space to explore and use local wisdom values as a standard of core character values, and encourage all principals to apply transformational leadership approaches based on the dimensions of teaching local culture.

As a study carried out in an educational environment, it certainly has implications in the field of education and other similar studies. In this regard, the implications of our research are as follows. First, the application of the cultural values of lonto leok culture as a standard for the main character values in schools has proven to be effective in supporting programs to strengthen education and have an impact on strengthening the character of students. Second, the principal's TLB based on the teaching dimensions of the lonto leok culture is very compatible with the work culture of teachers, employees, and is understood by parents, school committees, and the community. The impact is that all parties are actively involved in planning, implementing and evaluating work programs that have been determined, and the results are all programs are implemented optimally. 
Based on the results, this study contributed positively to the optimization of the implementation of CESP. During this time, the implementation of CES has not been carried out optimally in schools. Each school has not yet found a definite character education model, which results in an unclear application. To overcome the existing problems, the school principal who is supported by teachers, employees, parents, school committees, school supervisors, and cultural leaders takes the policy to use the moral values of local culture as the standard values of the main characters of the school. This policy is based on efforts to operationalize national character values that are still universal, conceptual, and anonymous. The policy of using local cultural values as a standard of school character values is considered as an innovative policy because it has only been found in the relevant school and not yet in other schools. Besides, this policy becomes a new and original knowledge in the implementation of character education. This policy can only be applied in other schools if local cultural values have the content of strengthening the character of students. Thus, it can be said that any policy formulation in any organization including educational organizations should pay attention to the operational formulation of program implementation, the environment, and the objectives to be achieved.

Besides, to support the inculcation of character values, the principle applies TLB developed by Podsakoff et al. (1990); Leithwood and Jantzi (2006) are supported by a pattern approach to the dimensions of local cultural teaching. The unification of leadership behavior and local cultural approach is assessed for its effectiveness by comparing traditional leadership concepts that contain national cultural values developed by Hofstede (2001), such as power distance, uncertainty, individualism and collectivism, masculinity. Based on the results of the study, it turns out there are similarities and differences in influence between national cultural values developed by Hofstede with the dimensions of lonto leok culture teaching in supporting the principal's leadership role. Thus, this research provides an original contribution to the development of local culture-based leadership concepts. National cultural values in the Hofstede concept are not all true. Therefore, the development of the concept of leadership in the future can unite TLB with local cultural approach patterns, as one of the innovative leadership models. On this basis, an effective leader needs to learn and apply local cultural approach patterns, whether he is from outside the local cultural environment, or from that cultural environment. This is based on the work performance of people who are led are conditioned by patterns of behavior that are influenced by the culture they live in.

\section{REFERENCES}

Ardiawan, K. N. 2018. “Ethnopedagogy and Local Genius: An Ethnographic Study.”SHS Web of Conferences 42, 00065 (2018). https://doi.org/10.1051/shsconf/20184200065.

Bass, Bernard M. 1997. "Does the Transactional-Transformational Leadership Paradigm Transcend Organizational and National Boundaries?” American Psychologist 52 (2): 130-139. https://doi.org/10.1037/0003-066X.52.2.130.

Bass, Bernard M., and Paul Steidlmeier. 1999. "Ethics, Character, and Authentic Transformational Leadership Behavior.” Leadership Quarterly. 10 (2): 181-218. https://doi.org/10.1016/S1048-9843(99)00016-8.

Cook, L. A., W. S. Smith, W. Y. Lan, and D. Carpenter. 2016. "The Development of Global Competencies and Global Mindedness through Global Education Experiences.” International Journal of Global Education 5 (2): 1-16.

Creswell, J. W. 2009. Research Design. Qualitative, Quantitative, and Mixed Method Approaches. Los Angeles: SAGE Publications, Inc.

Den Hartog, Deanne, N, Robert J. House, Paul, J. Hanges, and S. Antonio Ruiz-Quintanilla. 1999. "Culture-Specific and Cross-Culturally Generalizable Implicit Leadership 
Theories: Are Attributes of Charismatic/Transformational Leadership Universally Endorsed?” Leadership Quarterly 10 (2): 219-256.

Dix, C. R. 2013. "Leadership and Learning: The Impact of Transformational Leadership on Learning Culture Within Global Ministry Non-Profits.” Doctor of Education diss., Indiana Wesleyan University.

Erb, M. 2005. "Shaping a 'New Manggarai': Struggles over culture and tradition in an Eastern Indonesian regency." Asia Pacific Viewpoint 46 (3): 323-334. https://doi.org/10.1111/j.1467-8373.2005.00287.x.

Erikson, Erik, H. 1958. Young Man Luther: A Study in Psychoanalysis and History. New York: W. W. Norton.

Ferraro, G. P. 1998. The Cultural Dimensions of International Business. Englewood Clifffs, NJ: Prentice-Hall.

Government Regulation (PP) No. 87 of 2017. “Concerning Strengthening Character Education.” Office of Assistant to Deputy Cabinet Secretary, September 2017. [Is there a URL for this?]

Grant, M. A. 2012. "Leading with Meaning: Beneficiary Contact, Prosocial Impact, and the Performance Effects of Transformational Leadership.” Academy of Management Journal 55 (2): 458-476. https://doi.org/10.5465/amj.2010.0588.

Griffith, J. 2004. "Relation of Principal Transformational Leadership to School Staff Job Satisfaction, Staff Turnover, and School Performance.” Journal of Educational Administration 42 (3): 333-356. https:// doi.org/10.1108/09578230410534667.

Groves, Kevin, S. and M. A. LaRocca. 2011. “An Empirical Study of Leader Ethical Values, Transformational and Transactional Leadership, and Follower Attitudes Toward Corporate Social Responsibility.” Journal of Business Ethics 103 (4): 511-528. https://doi.org/10.1007/s10551-011-0877-y.

Hegel, G. W. F. (1807) 1979. Phenomenology of Spirit. Oxford: Oxford University Press.

Hofstede, Geert. 1984. Cultures Consequences: International Differences in Work-Related Values, abridged ed. Beverly Hills: Sage Publications.

1993. "Cultural Constraints in Management Theories." Academy of Management Executive 7: 81-94. https:// doi.org/10.5465/ame.1993.9409142061.

- 2001. Culture's Consequences: Comparing Values, Behaviors, Institutions, and Organizations Across Nations, 2nd ed. Thousand Oaks, CA: Sage Publications.

House, R. J., P. J. Hanges, S. A. Ruiz-Quintanilla, P. W. Dorfman, M. Javidan, M. Dickson, V. Gupta, V., et al. 1999. "Cultural Influences on Leadership and Organizations: Project GLOBE.” In Advances in Global Leadership, edited by W. Mobley, 71-234. Greenwich, CT: JAI Press.

Huang, J., and J. Farh. 2009. "Employee Learning Orientation, Transformational Leadership, and Employee Creativity: The Mediating Role of Employee Creative Self-Efficacy.” $\begin{array}{llllll}\text { Academy of Management Journal } 52 & \text { (4): 765-778. }\end{array}$ https://doi.org/10.5465/amj.2009.43670890.

Irawanto, D. W., P. L. Ramsey, and J. C. Ryan. 2011. "Challenge of Leading in Javanese Culture.” Asian $\quad$ Ethnicity $12 \quad$ (2): $125-139$. https://doi.org/10.1080/14631369.2011.571829

Kleden, Ignasius. 1987. Scientific Attitudes and Cultural Criticism. Jakarta : LP3ES.

Kocoska, J. 2009. "The student's position in the democratic classroom, in the World Conference on Educational Sciences." Procedia Social and Behavioral Sciences 1: 2429-2431. https//doi:10.1016/j.sbspro.2009.01.427.

Koesoema, Doni Albertus. 2015. Character Education: A Strategy for Educating Children in the Global Age. Jakarta: Grasindo.

2017. Character Education Strategy, Mental Revolution in Educational Institutions. Yogyakarta: Kanisius. 
Leithwood, Kenneth, and Doris Jantzi. 1999. “Transformational School Leadership Effects: A Replication.” School Effectiveness, and School Improvement 10 (4): 451-479.

2006. "Transformational School Leadership for Large-Scale Reform: Effects on Students, Teachers, and Their Classroom Practices.” School Effectiveness and School Improvement 17 (2): 201-227. https//doi.org/10.1080/09243450600565829.

Lickona, Thomas. 1996. "Eleven Principles of Effective Character Education.” Journal of Moral Education 25 (1): 93-100. https://doi.org/10.1080/0305724960250110.

2012. Education for Character: Educating for Character Shaping. Jakarta: PT Bumi Aksara.

Macneil, A. J., D. L. Prater, and S. Busch. 2009. “The Effect of School Culture and Climate on Student Achievement.” International Journal of Leadership in Education 12 (1): 7384.

Miles, M. B., A. M. Huberman, and J. Saldaña. 2014. Qualitative Data Analysis: A Methods Sourcebook, 3rd ed. Thousand Oaks, CA: SAGE Publications, Inc.

Musana, Al. 2011. "Local Wisdom Rationality and Actuality as a Character Education Base." Journal of Education and Culture 17 (6): 588-598.

Nieto, Sonia. 2008. “Culture and Education.” Yearbook of the National Society for the Study of Education 107 (1): 127-142. https://doi.org/10.1111/j.1744-7984.2008.00137.x.

Nggoro, Adi, M. 2013. Manggarai Culture at a Glance. Ende: Nusa Indah.

Obanya, P. 2005. "Culture in Education and Education in Culture.” Paper presented at Fifth Conference of African Ministers Of Culture, 10-14 December 2005, Nairobi, Kenya. www.africa-union.org.

Piccolo, Ronald F., and Jason A. Colquitt. 2006. "Transformational Leadership and Job Behaviors: The Mediating Role of Core Job Characteristics.” Academy of Management Journal 49 (2): 327-340. https://doi.org/10.5465/amj.2006.20786079.

Podsakoff, Philip M., Scott B. MacKenzie, Robert, H. Moorman, and Richard Fetter. 1990. "Transformational Leader Behaviors and Their Effects on Their Followers' Trust in the Leader, Satisfaction and Organizational Citizenship Behaviors." Leadership. Quarterly 1: 107-142. https://doi.org/10.1016/1048-9843(90)90009-7.

Power, F. C., and A. Higgins-D’Alessandro. 2008. “The Just Community Approach to Moral Education and the Moral Atmosphere of the School." In Handbook of Moral and Character Education, edited Larry P. Nucci and Darcia Narvaez, 230-247. New York, NY: Routledge, Taylor \& Francis Group.

Schein, E. H. 2004. Organizational Culture and Leadership, 3rd ed. San Francisco, CA: JosseyBass.

Schwartz, S. H. 1994. "Beyond Individualism/Collectivism: New Dimensions in Values.” In (Eds.), Individualism and Collectivism: Theory, Applications, and Methods, edited by U. Kim, H. C. Triandis, C. Kagitcibasi, S. C. Choi, and G. Yoon, 85-199. Thousand Oaks, CA: Sage.

Spreitzer, Gretchen M., Kimberly Hopkins Perttula, and Katherine Xin, 2005. “Traditionality Matters: an Examination of the Effectiveness Of Transformational Leadership in the United States and Taiwan.” Journal of Organizational Behavior 26 (3): 205-227. https://doi.org/10.1002/job.315.

Surya, I. B. K., A. Thoyib, A. Fatchan, and M. Rahayu. 2014. "Tri Hita Karana Culture Effect on Company Performance, Leadership and Organizational Commitment (Studies a Regional Water Company in Bali Province).” International Journal of Business and Management Invention 3 (6): 13-22.

Sutam, Inosensius. 2014. Education in the Perspective of Culture Manggarai. Ruteng: STKIP St. Paulus Ruteng.

Tapung, M., E. Maryani, Y. Lon, M. Payong, and N. Supriatna, N. 2018. "Developing the Value of "Lonto Leok" in Manggarai Culture to Empower the Skills of Social 
Problem-Solving in Social-Sciences Learning of Junior-High School.” In Proceedings of the Annual Conference on Social Sciences and Humanities (ANCOSH 2018). SCITEPRESS - Science and Technology Publications, Lda.

The Ministry of Education. 2010. Development of National Culture and Character Education. Jakarta: Secretariat Team.

The Ministry of Education. 2016. Strengthening Character Education. Jakarta: Secretariat Team.

The Ministry of Education. 2017. Strengthening Character Education Training Modules for School Principals. Jakarta: Secretariat Team.

UNESCO. 2012. Education of Sustainable Development. Sourcebook. France: United Nations Educational, Scientific and Cultural Organization.

Valentine, J., and M. Prater. 2011. "Instructional, Transformational, And Managerial Leadership and Student Achievement: High School Principals Make a Difference.” NASSP Bulletin 95 (1): 5-30. https://doi.org/10.1177/0192636511404062.

Veugelers, W. ed. 2008. "Getting involved. Global citizenship development and sources of moral values.” In Education and Humanism; Linking Autonomy and Humanity, AW Rotterdam,The Netherlands: Sense Publishers.

Wibowo, Ari. 2015. Character Education Management in Schools. Yogyakarta: Pustaka Pelajar.

Yammarino, F. J., A. J. Dubinsky, and W. D. Spangler. 1998. “Transformational and Contingent Reward Leadership: Individual, Dyad, and Group Level of Analysis.” The Leadership Quarterly 9 (1): 27-54.

Yaumi, Muhammad. 2014. Character Education: Platforms, Pillars \& Implementation. Jakarta: Predanamedia Group.

Yin, R. K. 2017. Case Study Research and Applications: Design and Methods. London: Sage publications.

Zamroni. 2011. Strategy and Model of Character Education Implementation in Schools. Yogyakarta: Universitas Negeri Yogyakarta.

\section{ABOUT THE AUTHORS}

Yulius Rustan Effendi: PhD Candidate, Department of Educational Management, Universitas Negeri Malang, Indonesia

Ibrahim Bafadal: Professor, Department of Education Management, Universitas Negeri Malang, Indonesia

I Nyoman Degeng Sudana: Professor, Department of Education Management, Universitas Negeri Malang, Indonesia

Imron Arifin: Professor, Department of Education Management, Universitas Negeri Malang, Indonesia 
The International Journal of Educational Organization and Leadership is one of ten thematically focused journals in the collection of journals that support The Learner Research Network -its journals, book series, conference, and online community.

The journal inquires into the nature and processes of effective educational administration and leadership.

As well as articles of a traditional scholarly type, this journal invites presentations of practice-including documentation of organizational and leadership practices, and exegeses of the effects of those practices.

The International Journal of Educational Organization and Leadership is a peer-reviewed, scholarly journal. 